\title{
Some Factors Affecting Host Susceptibility to Murine Hepatitis Virus
}

\author{
Masaharu NAIKI and Kôsaku FUJIWARA \\ Department of Animal Pathology, The Institute of Medical Science, \\ The University of Tokyo, Takanawa P. O. D., Tokyo.
}

(Received for publication, February 6, 1968)

\section{INTRODUCTION}

A virus capable of causing hepatitis in mice, JHM strain, was first isolated by Cheever et al [2] from mouse brain showing encephalitis. Gledhill et al [ 6 ] found another viral agent which showed enhanced liver necrosis in mice in association with Eperithrozoön coccocides. Since then, the hepatoencephalitis group of viruses was shown to be widely distributed in many laboratory mouse colonies.

In Japan, a virus strain causing fatal encephalitis in suckling mice and related antigenically to murine hepatitis viruses was isolated by Morris [10] from naturally infected albino mice from commercial sources. In the course of studies on Tyzzer's disease Fujiwara [4] also obtained another strain of the virus causing necrotic hepatitis after treating inoculated animals with a large dose of cortisone and found that the virus shares common antigen with MHV-2 [11] in complement fixation reaction. To this virus strain of comparatively low virulence, ICR mice were shown to be much more sensitive than DDD mice. Although it has been mentioned that there is much difference in susceptibility to murine hepatitis virus with mouse strains and ages $[1,6,11]$, no detail observations have been made in these respects with Japanese indigenous mouse strains as well as ICR mice. Then, the susceptibility of murine hepatitis virus was compared at varing ages to that of other strains of mice available in this institute, as a first step of working on pathogenesis, immunity and epizootiology of murine viral hepatitis that remain mostly still obscure.

\section{METHODS}

Mice-Barrier-sustained male and females ICR mice as well as conventional male DDY mice were obtained from commercial sources. Male
$\mathrm{CF} \sharp 1, \mathrm{C} 57 \mathrm{BL} / 6$ and DDD mice were bred at this Institute. All the animals were brought to the laboratory at ages 4 to 7 weeks and maintained on water and commercial pellets (MNF, Oriental Yeast Co., Ltd., Tokyo).

Virus Mouse hepatitis virus, MHV-2 (MHV (Pr)) [11] was supplied by the courtesy of Dr. S. Suzuki, Institute for Virus Research, Kyoto University. The virus was maintained by serial pasages in ICR mice of age 4 weeks or stored at $-20^{\circ} \mathrm{C}$. Materials for inoculation were prepared from fresh infected liver. Homogenate of infected livers in phosphate buffer saline, $\mathrm{pH} 7.2$ (PBS) was made by a glass homogenizer and centerifuged at $8,000 \mathrm{rpm}$ for 30 minutes. Then the supernatant was used for inoculation. The $\mathrm{LD}_{50}$ was calculated using 4-week-old ICR mice according to the method of Reed and Muench [12].

Experimental infection. Inoculation of the virus was made in most cases intravenously with $0.1 \mathrm{ml}$ of serial tenfold dilutions of infected mouse liver homogenate. At times, mice were infected also intraperitoneally or subcutaneously. Observation was made for 10 days following the inoculation and death was recorded each day. From time to death in days harmonic means with 95 percent confidence range were calculated in each experimental group.

Complement fixation (CF) test.-Antigen was prepared from severely infected ICR mouse liver with MHV-2. Homogenate of the livers in PBS (1:10) was centrifuged at $8,000 \mathrm{rpm}$ for $20 \mathrm{~min}$ utes. To the supernatant was added an equal volume of ethyl-ether and, after agitation, the mixture was stored at $4^{\circ} \mathrm{C}$ for 48 hours. Then, after centrifugation for elimination of ether-extracted substance and evaporation of ether, the water layer was used as an antigen. A 1:8 dilution of sera of retired breeder mice of age 25 to 30 weeks collected from different colonies was subjected individually to $C F$ test with 4 units of the antigen, according to the method described previous- 
Table 1. Response of different strains of mice to MHV-2 infection

\begin{tabular}{|c|c|c|c|c|c|c|c|}
\hline \multirow{2}{*}{ Age } & \multirow{2}{*}{$\begin{array}{l}\text { Dose } \\
\text { (i. v.) }\end{array}$} & \multicolumn{6}{|c|}{ Mouse strain } \\
\hline & & & ICR & $\mathrm{CF} \sharp 1$ & DDD & $\mathrm{C} 57 \mathrm{BL} / 6$ & DDY \\
\hline \multirow[t]{5}{*}{4 weeks } & $10^{5} \times \mathrm{LD}_{50}$ & $5 / 5^{*}$ & $(100 \%)$ & & & $10 / 10(100 \%)$ & $7 / 10(70 \%)$ \\
\hline & $10^{4}$ & $5 / 5$ & $(100 \%)$ & $14 / 17(82 \%)$ & $19 / 31(61 \%)$ & $6 / 10(60 \%)$ & $5 / 9 \quad(56 \%)$ \\
\hline & $10^{3}$ & $5 / 5$ & $(100 \%)$ & $10 / 16(63 \%)$ & $6 / 22(27 \%)$ & $3 / 10(30 \%)$ & $2 / 11(18 \%)$ \\
\hline & $10^{2}$ & $5 / 5$ & $(100 \%)$ & & & $2 / 10(20 \%)$ & \\
\hline & 10 & $5 / 5$ & $(100 \%)$ & & & $1 / 10(10 \%)$ & \\
\hline \multirow[t]{4}{*}{5 weeks } & $10^{5} \times \mathrm{LD}_{50}$ & $9 / 9$ & $(100 \%)$ & & & & $4 / 9 \quad(45 \%)$ \\
\hline & $10^{4}$ & $7 / 10$ & $(70 \%)$ & $3 / 10(30 \%)$ & $2 / 22(9 \%)$ & & $0 / 11$ \\
\hline & $10^{3}$ & $7 / 10$ & $(70 \%)$ & $0 / 10$ & $2 / 27(8 \%)$ & & $0 / 11$ \\
\hline & $10^{2}$ & $4 / 10$ & $(40 \%)$ & & & & \\
\hline
\end{tabular}

* Dead/Inoculated within 10 days after inoculation.

All mice were kept in the laboratory since the age of 4 weeks.

ly $[4]$.

\section{RESULTS}

Mice of DDD, DDY, CF $\sharp 1, C 57 B L / 6$ and ICR strains that had arrived at the laboratory at age 4 weeks were inoculated intravenously with 10 to $10^{5} \times \mathrm{LD}_{50}$ of the virus either on arrival or 1 week later. As shown in Table 1 , ICR mice were shown to be the most sensitive, while CF $\# 1$ mice of the same age were somewhat more susceptible as compared to DDY, DDD and C57BL/ 6 mice. Moreover, susceptibility of all these strains of mice seemed to be reduced evidently after maintenance for 1 week at the laboratory. The next experiment was performed to study relationship between the response of ICR mice and their age at intravenous inoculation. Thirty-five ICR mice were brought to the laboratory from the barrier- ed breeder colony at the age of 3 weeks, and 7 to 10 animals each were inoculated intravenously

Table 2. Response of barrier-sustained ICR mice of different ages to MHV-2 infection

\begin{tabular}{|c|c|c|}
\hline Age & $\begin{array}{l}\text { Dead/Inocu- } \\
\text { lated* }\end{array}$ & $\begin{array}{l}\text { Time to death in } \\
\text { day** }\end{array}$ \\
\hline 3 weeks & $9 / 9$ & 2.0 \\
\hline "I & $9 / 9$ & $2.7(2.3-3.2)$ \\
\hline$\prime \prime$ & $7 / 7$ & $3.6(2.9-4.8)$ \\
\hline II & $7 / 10$ & $4.6(3.1-9.0)$ \\
\hline
\end{tabular}

* Within 10 days after i. v. inoculation with $10^{4} \times \mathrm{LD}_{50}$.

** Harmonic mean with $95 \%$ confidence range in perenthesis. All mice were kept in the laboratory since 3 weeks of age. with $10^{4} \times \mathrm{LD}_{50}$ virus either on arrival or 1 to 3 weeks later. As shown in Table 2, all the 3-weekold mice infected on arrival at this laboratory died within 48 hours after inoculation. In animals infected 1,2 and 3 weeks after arrival, harmonic means of time to death were more prolonged and $2.7,3.5$ and 4.6 days respectively. Three of 10 mice infected after maintenance for 3 weeks at the laboratory survived the infection. Age difference in susceptibility was further studied with ICR mice purchased at the age of 4 and 6 weeks and infected with varying doses of virus. Male ICR mice of the both ages were infected intravenously with $10^{5}$ to $1 \times \mathrm{LD}_{50}$ virus. Harmonic

Table 3. Response of barrier-sustained ICR mice at the ages of 4 and 6 weeks to MHV-2 infection

\begin{tabular}{cccc}
\hline Age & $\begin{array}{l}\text { Dose } \\
\text { (i. v.) }\end{array}$ & $\begin{array}{c}\text { Dead/ } \\
\text { Inoculated* }\end{array}$ & $\begin{array}{c}\text { Time to death** } \\
\text { in days }\end{array}$ \\
\hline 4 weeks & $10^{5} \times \mathrm{LD}_{50}$ & $10 / 10$ & $2.4(2.1-2.8)$ \\
$14^{4}$ & $10 / 10$ & $2.5(2.1-3.0)$ \\
$13^{3}$ & $10 / 10$ & $3.2(2.9-3.4)$ \\
$10^{2}$ & $10 / 10$ & $3.7(3.2-4.3)$ \\
10 & $6 / 10$ & $7.8(4.9-18.9)$ \\
1 & $4 / 10$ & $11.6(5.8-\infty)$ \\
\hline 6 weeks $10^{5}$ & $10 / 10$ & $3.7(3.1-4.6)$ \\
$10^{4}$ & $10 / 10$ & $4.5(3.7-5.6)$ \\
$10^{3}$ & $5 / 5$ & $5.6(4.2-8.1)$ \\
$10^{2}$ & $4 / 5$ & $7.1(4.2-8.1)$ \\
10 & $5 / 5$ & $5.7(4.8-6.7)$ \\
1 & $3 / 5$ & $10.4(4.2-\infty)$ \\
\hline
\end{tabular}

* Within 10 days after inoculation.

** Harmonic mean with $95 \%$ confidence range in parenthesis. 


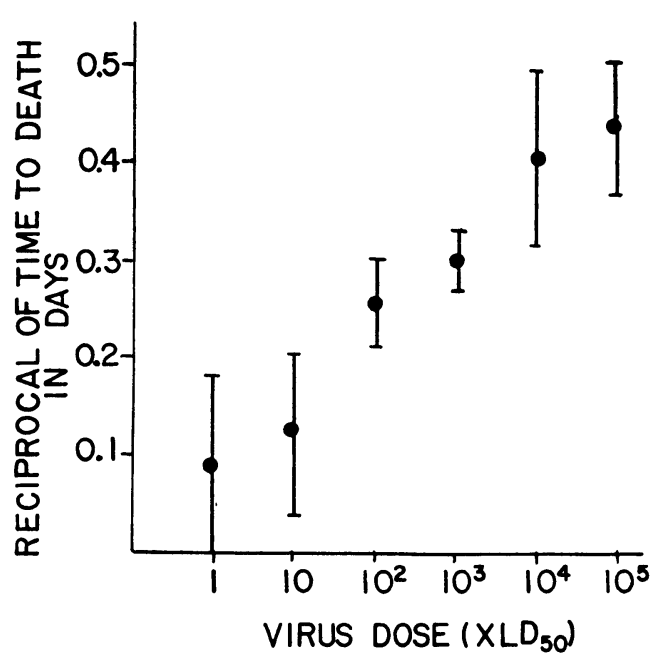

Fig 1. Correlation between time to death and dose of virus inoculation in $\mathrm{MHV}-2$ infection of 4-week-old ICR mice. Vertical line at each point shows a 95\% confidence range. From data presented in Table 3 .

means of time to death in 4-week-old mice were $2.4,2.5,3.2,3.7,7.8$ and 11.6 days, while in 6 week-old mice they were $3.7,4.5,5.6,7.1,5.7$ and 10.4 days respectively (Table 3 ). Time to death for each viral dose formed a hyperbolic curve, and reciprocals of time to death correspond. ing to each viral dose were distributed linearly in the 4-week-old animals as shown in Fig. 1.

Also with ICR mice, the infectivity by various routes of inoculation was compared. Male mice aged 4 weeks were inoculated with $10^{3} \times \mathrm{LD}_{50}$ by intravenous, intraperitoneal or subcutaneous route. As shown in Table 4 , means of time to death were $3.0,3.6$, and 4.4 days after intravenous, intraperitoneal and subcutaneous inoculation respectively. Thus, infectivity was the most prominent and variance of time to death was of a minimum after intravenous inoculation.

Table 4. Response of barrier-sustained 4-week old ICR mice infected with MHV.2 by various routes

\begin{tabular}{ccc}
\hline $\begin{array}{c}\text { Route of } \\
\text { Inoculation }\end{array}$ & $\begin{array}{c}\text { Dead/ } \\
\text { Inoculated* }\end{array}$ & $\begin{array}{c}\text { Time to death } \\
\text { in days** }\end{array}$ \\
\hline i. v. & $5 / 5$ & 3.0 \\
i. p. & $5 / 5$ & $3.6(2.9-4.7)$ \\
s. c. & $5 / 5$ & $4.4(3.3-6.5)$ \\
\hline
\end{tabular}

* Within 10 days after infection with $10^{3} \times \mathrm{LD}_{50}$.

** Harmonic mean with $95 \%$ confidence range in parenthesis.

All mice were inoculated on arrival at the laboratory.
The sensitivity of ICR mice that had arrived at the age of 3 or 4 weeks seemed to decrease after maintenance for 2 weeks at this laboratory as described above. However, as shown in Table 3 , such decrease in the susceptibility was not so evident, when animals were maintained within the barriered breeder colony up to the age of 6 weeks and then brought to the laboratory. To examine a possidle contamination in this laboratory, where the population of varied strains of mice from conventional sources were much dense, the following experiments were attempted. Thirty animals each were supplied from the barriered breeder colony at the age of $4,5,6$ or 7 weeks and infected intravenously with 0.1 to $10^{4} \times \mathrm{LD}_{50}$ of virus 3 days after arrival. Of other 89 mice that had arrived at the age of 4 weeks at this laboratory, 49 animals were infected intravenously with the same doses of virus after main-

Table 5. Response of ICR mice sustained at either barriered breeder colony or laboratory to MHV-2 infection

\begin{tabular}{|c|c|c|c|c|c|}
\hline \multirow{2}{*}{ Maintenance } & \multirow{2}{*}{$\begin{array}{l}\text { Dose of } \\
\text { Inoculation } \\
\quad \text { (i. v.) }\end{array}$} & \multicolumn{4}{|c|}{$\begin{array}{c}\text { Age in weeks at } \\
\text { inoculation }\end{array}$} \\
\hline & & 4 & 5 & 6 & 7 \\
\hline \multirow{6}{*}{$\begin{array}{l}\text { Barriered } \\
\text { breeder* } \\
\text { colony }\end{array}$} & $10^{4} \times \mathrm{LD}_{50}$ & $5 / 5^{* *}$ & $5 / 5$ & $5 / 5$ & $5 / 5$ \\
\hline & $10^{3}$ & $5 / 5$ & $4 / 5$ & $5 / 5$ & $4 / 5$ \\
\hline & $10^{2}$ & $5 / 5$ & $3 / 5$ & $4 / 5$ & $4 / 5$ \\
\hline & 10 & $5 / 5$ & $0 / 5$ & $1 / 5$ & $2 / 5$ \\
\hline & 1 & $3 / 5$ & $1 / 5$ & $1 / 5$ & $0 / 5$ \\
\hline & 0.1 & $2 / 5$ & $2 / 5$ & $1 / 5$ & $1 / 5$ \\
\hline \multirow[t]{6}{*}{ Laboratory** } & $10^{4} \times \mathrm{LD}_{50}$ & & $9 / 9$ & $0 / 5$ & $0 / 5$ \\
\hline & $10^{3}$ & & $7 / 10$ & $0 / 5$ & $0 / 5$ \\
\hline & $10^{2}$ & & $7 / 10$ & $0 / 5$ & $0 / 5$ \\
\hline & 10 & & $4 / 10$ & $0 / 5$ & $0 / 5$ \\
\hline & 1 & & $2 / 5$ & & \\
\hline & 0.1 & & $2 / 5$ & & \\
\hline
\end{tabular}

* Maintained within the barrier before inoculation.

** Maintained at laboratory since 4 weeks of age.

*** Dead/Inoculated within 10 days after inoculation.

tenance for 1 week at the laboratory. The remaining animals were inoculated with the same serial doses of virus after maintenance for 2 or 3 weeks. The results were shown in Table 5. After maintenance for 2 weeks in the laboratory mice seemed to show much higher resistance than those kept within the barriered breeder colony. In this experiment, mice maintained within the barrier up to age 5 weeks were shown to be more resistant as compared to the results pre- 
Table 6. Response of ICR mice bred at either barriered breeder colony or laboratory to MHV-infection

\begin{tabular}{lccccccc}
\hline \multirow{2}{*}{\begin{tabular}{c} 
Source of animals \\
\cline { 3 - 7 }
\end{tabular}} & Age in days & \multicolumn{5}{c}{ Dose of virus inoculation $\left(\times \mathrm{LD}_{50}\right.$ i. v. $)$} \\
\cline { 3 - 7 } & & $10^{5}$ & $10^{4}$ & $10^{3}$ & $10^{2}$ & 10 & 1 \\
\hline $\begin{array}{c}\text { Barriered breeder } \\
\text { colony* }\end{array}$ & $28-30$ & $8 / 8^{* *}$ & $8 / 8$ & $8 / 8$ & $8 / 8$ & $8 / 8$ & $7 / 8$ \\
\hline Laboratory & $6-8$ & $2 / 5$ & $0 / 5$ & $0 / 16$ & $2 / 17$ & $0 / 17$ & $0 / 10$ \\
& $17-20$ & $3 / 10$ & $5 / 10$ & $3 / 10$ & $0 / 10$ & $0 / 10$ & $0 / 10$ \\
& 22 & $2 / 10$ & $0 / 10$ & $0 / 10$ & $0 / 10$ & $0 / 10$ & $0 / 10$ \\
& $28-31$ & $4 / 10$ & $1 / 10$ & $0 / 10$ & $0 / 10$ & $0 / 10$ & $0 / 10$ \\
\hline
\end{tabular}

* Inoculated on arrival at the laboratory.

** Dead/Inoculated within 10 days after inoculation.

sented in Table 3, while the susceptibility was remarkably high in 4-week-old animals. However, the barrier-sustained animals died of the infection with the highest dose of virus even at the age of 6 and 7 weeks. Although the mice kept in the laboratory since the age of 4 weeks showed also a moderate susceptibility when infected at the age of 5 weeks, a marked resistance seemed to be established at the age of 6 to 7 weeks.

In the next experiments, sacklings, weanlings and adults of ICR mice bred at this laboratory were subjected to inoculation test as compared to those bred within the barriered breeder colony. Five to 20 animals of each age were inoculated intravenously with $10^{5}$ to $1 \times \mathrm{LD}_{50}$ virus. As shown in Table 6, sacklings or weanlings bred at the laboratory were found to be resistant to the virus infection and only a part of the mice died within 10 days even after inoculation made 6 to 7 days after birth with $10^{5} \times \mathrm{LD}_{50}$ virus. On the contrary, all the mice that had been brought from the barriered breeder colony at 4 to 5 weeks of age died of the infection with $10 \times \mathrm{LD}_{50}$ virus.

The foregoing experiments suggest that contamination with the virus among breeder colonies might affect considerably the susceptibility of

Table 7. Complement fixation test of retired breeder mouse sera with MHV-2 (March 1967 December 1967)

\begin{tabular}{lcr}
\hline Breeder colony & Mouse strain & CF positivity \\
\hline This institute & DDD & $7 / 532 *(1.3 \%)$ \\
& BALB/C & $2 / 149(1.3 \%)$ \\
\hline Commercial & & \\
Conventional & DDY & $63 / 3,236(1.9 \%)$ \\
Barriered & ICR & $4 / 1,575(0.3 \%)$ \\
\hline
\end{tabular}

* No. of sera showing positive reaction at a 1: 8 dilution with 4 units of antigen/No. of sera tested. animals. In fact, complement fixation tests with retired breeder mouse sera collected from different breeder colonies revealed that the barriered colony supplying the most susceptible ICR mice seemed to be contaminated in a less degree than other colonies (Table 7). However, the degree of contamination in the latters seemed to be too low to provide a uniform resistance acquired coincidentally by most of animals, although CF antibody might be less persistent than neutralizing antibody, and moreover, latent infections were more frequently detected in 4-week-old ICR mice from the barrired colony than other mice from conventional colonies (Unpublished observations).

\section{DISCUSSION}

Gledhill et al [6] reported that the VS strain of mice were more sensitive to MHV-1 infection than $\mathrm{P}, \mathrm{C} 3 \mathrm{H}$ and $\mathrm{C} 57 \mathrm{BL} / 6$ strains, and Nelson [11] found that Swiss and other strains of mice were much more resistant to $\mathrm{MHV}$-infection than Pr mice. Recently, Bang [1] showed that macrophages from $\mathrm{C} 3 \mathrm{H}, \mathrm{CFW}$ and the Webster mice were resistant to MHV-2. On the contrary, Manaker et al. [9] showed that there were no differcnces in susceptibility to A-51 virus infection among $\mathrm{C} 57 \mathrm{BL} / 6$, Swiss, $\mathrm{A}$ and $\mathrm{C} 3 \mathrm{H}$ strains of mice. In the present experiments, ICR mice were found to be the most susceptible among the strains of mice examined. A yield of virus titers of $10^{7}$ to $10^{8} \times \mathrm{LD}_{50}$ per $\mathrm{g}$ liver tissue was obtained constantly at death following intravenous inoculation into 3 - to 4 -week-old ICR mice. It is comparable to the results using $\mathrm{Pr}$ mice described by Nelson [11] and Bang et al [1].

Such a constant response of ICR mice was shown only up to 4 weeks of age and the animals became evidently less susceptible since 5 weeks of age. The difference in susceptibility with age have not been indicated in detail by Nelson [11] 
using the same virus as in the present experiments. However, it was described that virulence of MHV-1, MHV-3 and A-59 viruses were different with age of infected mice and that infant and weanling mice were much more susceptible than the adult $[3,7,9]$.

Most of 4-week-old ICR mice infected with fatal doses of the virus died within 2 to 5 days following inoculation. Reciprocals of time to death were correlated in a linear relation with logarithmic doses of virus inoculation. Nevertheless, as shown in Table 2 and 3, such susceptibility of ICR mice was demonstrated neither when barrier-sustained animals were infected at 6 weeks of age nor when breeding was made outside of the barrier. These observations might be not perfectly comparable to those described by Bang [1] using $\mathrm{Pr}$ and $\mathrm{C} 3 \mathrm{H}$ mice, because only genetic factors seemed to be involved in his cases. On the other hand, possible contamination with the virus was suggested from the fact that somewhat more persistent susceptibility was shown when animals were maintained in the barriered breeder colony before use. A resistance observed in sucklings bred at the laboratory was probably due to maternal antibodies. Rowe et al [13] showed that the CD-1 mice maintained free from MHV were infected when exposed to conventional environment and Manaker [9] also demonstrated that the BALB/C mice nursed by their parents that had been previously infected were more resistant to infection with $10^{3} \times \mathrm{LD}_{50}$ of A59 virus than controls.

In the present studies, serological evidence seems not to be enough to explain that precocious development of resistance cutside of the barrier is attributed to sensitization by latent infection, since complement fixing antibody positivities remained within a low range in these breeder colonies supplying comparatively resistant mice other than ICR. The results were compatible with a preliminary report [5]. It might be possible for animals to acquire non-specific resistance to $\mathrm{MHV}$ in conventional environment, for example by some other viral infections resulting in interferon induction. Moreover, although the antibodies were quite rarely demonstrable in retired breeder mouse sera, a low-virulence hepatitis virus that shares common antigen with $\mathrm{MHV}-2$ was isolated from cortisone-treated young mice of the barriered breeder colony [4]. Nevertheless, young ICR mice from this colony showed always a constant response to experimental infection of MHV-2. Ecology of such low virulence virus is of great interest and will be published later.

Some other factors as different dietary conditions in each environments also might be involved in the host susceptibility to the virus, since it was reported to affect the course of bacterial [8] and viral [14] necrotic hepatitis.

\section{SUMMARY}

ICR mice (barrier-sustained) were found to be much more susceptible to experimental infection of murine hepatitis virus than CF $\# 1$, DDD, DDY, and $\mathrm{C} 57 \mathrm{BL} / 6$ mice (conventional). The response of 4-week-old ICR mice was correlated in a linear relation with dose of virus inoculation. The susceptibility to the virus lowered remarkably with age and more precociously in conventional environment than within the barrier. Possible rôles of the virus contamination in the mouse colonies for this problem were discussed. It may be reasonable to consider that maintenance within the barrier is not an only main cause of the high susceptibility of ICR mice to murine hepatitis virus.

\section{ACKNOWLEDGEMENTS}

The authors are indebted to Professor Y. Tajima, The Institute of Medical Science, Univer. sity of Tokyo, for his constant encouragement on these studies. Thanks are also expressed to Dr. T. Nomura, Director of Central Institute for Experimental Animals, for making available to the authors the use of the barrier-sustained animals.

\section{REFERENCES}

[1] Bang, F. B. : Mouse macrophages as host cells for the mouse hepatitis virus and the genetic basis of their susceptibility. Rroc. Nat. Acad. Sci., 46, 1055-1075, (1960).

[2] Cheever, F. S., Daniels, J. B., Pappenheimer, A. M. and Bailey, O. T.: A murine virus (JHM) causing disseminated encephalomyelitis with extensive destruction of mye lin. I. Isolation and biological properties of the virus. J. Exp. Med., 90, 181-194, (1949).

[3] Dick, G. W. A., Niven, J. S. F. and Gledhill, A. W. : A virus related to that causing hepatitis in mice (MHV). Brit. J. Exp. Path., 37, 90-98, (1956).

[4] Fujiwara, K. : Complement fixation reaction and agar gel double diffusion test in Tyzzer's disease of mice. Japan. J. Microbiol., 11, 103-117, (1967).

[5] Fujiwara, K: An attempt to check five infections in breeding colonies with retired breeder mouse sera. Bull. Exp. Animals, 16, 47-51, (1967).

[6] Gledhill, A. W. and Andrewes, C. H. : A hepatitis virus of mice. Brit. J. Exp. Path., 
32, 559-568, (1951).

[7] Gledhill, A. W., Dick, G. W. A. and Niven, J. S. F. : Mouse hepatitis virus and its pathogenic action. J. Path. Bact., 69, 299-309, (1955).

[8] Maejima, K., Fujiwara, K., Takagaki, Y., Naiki, M., Kurashina, H. and Tajima, Y. :

Dietetic effects on experimental Tyzzer's disease of mice. Japan. J. Exp. Med., 35, 110, (1965).

[9] Manaker, R. A., Piczak, C. V., Miller, A. A and Stanton, M. F. : A hepatitis virus complicating in studies with mouse leukemia. J. Nat. Cancer Inst., 27, 29-51, (1961).

[10] Morris, J. A. : A new member of hepatoencephalitis group of murine viruses. Proc. Soc. Exp. Biol. Med., 100, 875-877, (1959).
[11] Nelson, J. B.: Acute hepatitis associated with mouse leukemia. II. Etiology and host range of the causal agent in mice. J. Exp. Med., 96, 303-312, (1952).

[12] Reed, L. J. and Muench, H. : A simple method of estimating fifty per cent endpoints. Amer. J. Hyg., 27, 493, (1938).

[13] Rowe, W. P., Hartley, J. W. and Capps, W. I. : Mouse hepatitis virus infection as a highly contageous, prevalent, enteric infection of mice. Proc. Soc. Exp. Biol. Med., 112, 161-165, (1963).

[14] Ruebner, B. and Branhall, J. L. : Effect of dietary protein on the severity of experimental mouse hepatitis. Nature, 183, 609610, (1959).

\section{マウス肝炎ウィルス感受性に影響する \\ 因子について}

内 貴 正治・藤原公策

東京大学医科学研究所獣医学研究部

マウス肝炎ウィルス（MHV-2 株）に対する感受性を マウス系統日令，環境などについて比較し次の成績をえ た。

ICR マウス（いわゆる barrier system で維持繁殖） は CF\#1, DDD, DDY, C57BL/6 (conventional) の 各マウスにくらべて肝炎ウィルスに対する感受性が著し
く高く， 4 週令 ICR マウスでは接種ウィルス量と反応 との間に直線的な関係がみられた。このょうな ICR マ ウスの高い感受性は週令とともに低下し, conventionl な環境ではより早期に抵抗性が高まるようであったが, 群のウィルス污染の有無とは直接関係ない上うであっ た。 